\title{
Supporting Information \\ For \\ Palladium-Catalyzed Cross-Coupling Reactions Between Dihydropyranylindium \\ Reagents and Aryl Halides. \\ Synthesis of C-Aryl Glycals
}

Ute Lehmann, Smita Awasthi, and Thomas Minehan*

$\underline{\text { General Procedure for Preparation of Trisdihydropyranyl indium(III) } 1}$<smiles>C1=COCCC1</smiles>

$\frac{\text { 1. } t \text { - BuLi } / \mathrm{THF} /-78^{\circ} \mathrm{C} \text { to } 0^{\circ} \mathrm{C}}{\text { 2. } 0.33 \text { eq. } \ln \mathrm{Il}_{3}, \mathrm{THF} /-78^{\circ} \mathrm{C} \text { to rt }}$

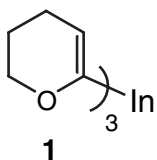

To a stirred solution of $0.60 \mathrm{ml}$ of dry THF and 3,4-dihydro-2H-pyran $(0.273 \mathrm{~mL}$, $3 \mathrm{mmol}$ ) was added dropwise a solution of $t$-butyllithium solution $(2.1 \mathrm{~mL}, 3.57 \mathrm{mmol}$, 1.7 $\mathrm{M}$ in pentane) at $-78^{\circ} \mathrm{C}$ under dry $\mathrm{N}_{2}$. The resulting yellow suspension was stirred at $0^{\circ} \mathrm{C}$ for 1 hour whereby a clear yellow solution was obtained. The solution was added at $-78^{\circ} \mathrm{C}$ to a solution of indium(III) chloride $(0.221 \mathrm{~g}, 1 \mathrm{mmol})$ in dry THF $(1.5 \mathrm{ml})$. The mixture was stirred at this temperature for 30 minutes and was then allowed to warm to room temperature, during which time a white suspension formed. This procedure gives an approximately $0.25 \mathrm{M}$ solution of $\mathbf{1}$.

$\underline{\text { General Procedure for Coupling of Triorganoindiums }}$

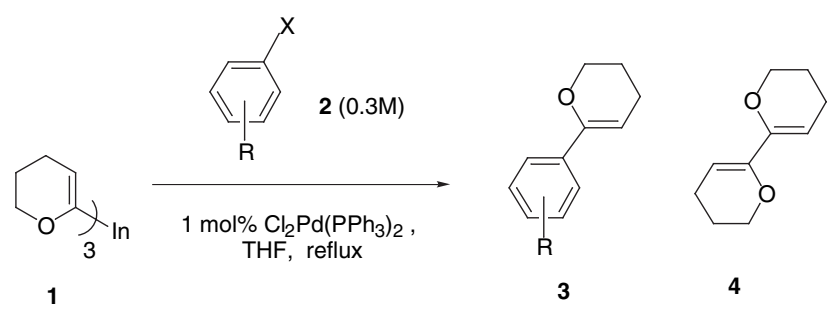

Compound 1 was added to a stirring mixture of aryl bromide $(0.9-1.0 \mathrm{mmol})$ in dry THF $(1.5 \mathrm{~mL})$ and palladium catalyst $(1-5 \mathrm{~mol} \%)$ at reflux. The resulting mixture was refluxed under dry $\mathrm{N}_{2}$ for 1-2 hours. The progress of the reaction was monitored by TLC and GC/MS. The mixture was then quenched by the addition of a few drops of methyl alcohol. The suspension was filtered through a short plug of celite. Purification of the residue by column chromatography afforded the coupled product. 


\section{$\underline{\text { Reaction of 4-bromoacetophenone } 2 \mathrm{a} \text { with } 1}$}

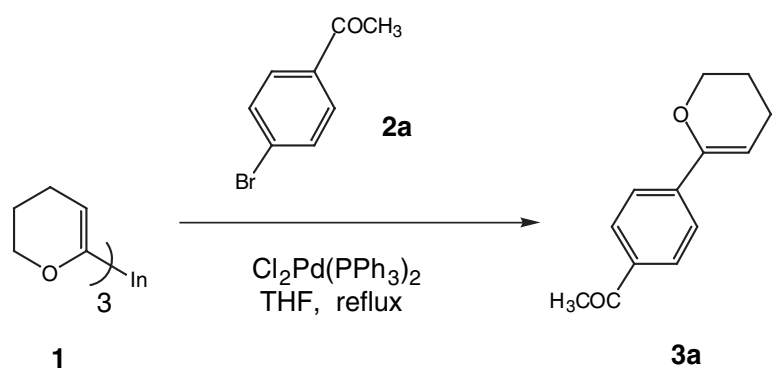

Following the general procedure, a $0.25 \mathrm{M}$ THF solution of $1(1.32 \mathrm{~mL}, 0.33$ mmol, 0.33 equiv) was added to a refluxing solution of dry THF (1.5 mL), 4bromoacetophenone $2 \mathbf{a}(0.179 \mathrm{~g}, 0.9 \mathrm{mmol})$ and $\left(\mathrm{PPh}_{3}\right)_{2} \mathrm{PdCl}_{2}(7 \mathrm{mg}, 0.01 \mathrm{mmol})$. The resulting mixture was refluxed for $1 \mathrm{~h}$ under dry $\mathrm{N}_{2}$. The progress of the reaction was monitored by TLC and GC/MS. The reaction was then quenched by the addition of a few drops of methyl alcohol. The suspension was filtered through a short plug of celite. Purification of the residue by column chromatography $\left(\mathrm{SiO}_{2}\right.$, hexane / EtOAc, 20 / 1) gave a $3 \mathbf{a}$ as a colorless oil $(65.7 \mathrm{mg}, 0.324 \mathrm{mmol}, 36.0 \%$ isolated yield).

Data for 3a:

${ }^{1} \mathrm{H}$ NMR: $\left(400 \mathrm{MHz}, \mathrm{CDCl}_{3}\right)$

$7.91(\mathrm{~d}, J=8.4 \mathrm{~Hz}, 2 \mathrm{H}) ; 7.62(\mathrm{~d}, J=8.4 \mathrm{~Hz}, 2 \mathrm{H}) ; 7.37(\mathrm{~s}) ; 5.51(\mathrm{t}, J=4.2 \mathrm{~Hz}$, $1 \mathrm{H}) ; 4.20(\mathrm{dd}, J=5.2,5.2 \mathrm{~Hz}, 2 \mathrm{H}) ; 2.59(\mathrm{~s}, 3 \mathrm{H}) ; 2.26(\mathrm{~m}, 2 \mathrm{H}) ; 1.93(\mathrm{~m}, 2 \mathrm{H})$

${ }^{13} \mathrm{C}$ NMR: $\left(100 \mathrm{MHz}, \mathrm{CDCl}_{3}\right)$

$198.0 ; 151.3 ; 141.0 ; 130.2 ; 128.7 ; 124.6 ; 100.4 ; 66.9 ; 26.9 ; 22.6 ; 21.4$

HRMS: $\quad\left(\right.$ EI+) calculated for $\mathrm{C}_{13} \mathrm{H}_{14} \mathrm{O}_{2} 202.0994$, found $\mathrm{m} / z=202.0998$

TLC: $\quad \mathrm{R}_{\mathrm{f}} 0.28\left(\mathrm{SiO}_{2}\right.$, hexane / EtOAc, $\left.20 / 1\right)$

GC: $\quad t_{\mathrm{R}} 3 \mathbf{a}, 10.06 \min \left(\mathrm{HP} 5890\right.$; injector $250^{\circ} \mathrm{C}$, column gradient $110^{\circ} \mathrm{C}$ for $3 \mathrm{~min}$, $25^{\circ} \mathrm{C}$ per min to $200^{\circ} \mathrm{C}, 200^{\circ} \mathrm{C}$ for $8 \mathrm{~min}$; $8.4 \mathrm{psi}$ ) 


\section{$\underline{\text { Reaction of Ethyl-4-bromobenzoate with } \mathbf{1}}$}

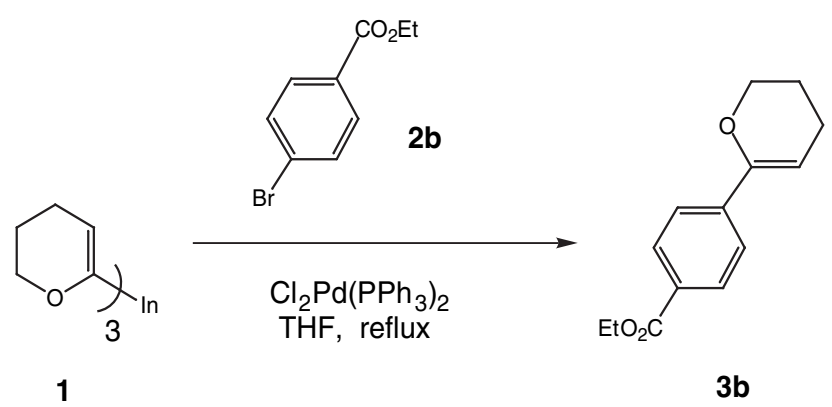

Following the general procedure, a $0.25 \mathrm{M}$ THF solution of $\mathbf{1}(1.32 \mathrm{~mL}, 0.33$ mmol, 0.33 equiv) was added to a refluxing solution of dry THF (1.5 mL), ethyl-4bromobenzoate $2 \mathbf{b}(0.147 \mathrm{~mL}, 0.9 \mathrm{mmol})$ and $\left(\mathrm{PPh}_{3}\right)_{2} \mathrm{PdCl}_{2}(7 \mathrm{mg}, 0.01 \mathrm{mmol})$. The resulting mixture was refluxed for $1 \mathrm{~h}$ under dry $\mathrm{N}_{2}$. The progress of the reaction was monitored by TLC and GC/MS. The reaction was then quenched by the addition of a few drops of methyl alcohol. The suspension was filtered through a short plug of celite. A few drops of $\mathrm{NEt}_{3}$ in hexane were added to a silica-gel slurry before loading the column for chromatography. Purification of the residue $\left(\mathrm{SiO}_{2}\right.$, hexane / EtOAc, 20 / 1) gave a 3b as a colorless oil (52 mg, $0.224 \mathrm{mmol}, 24.8 \%$ yield).

Data for 3b:

${ }^{1} \mathrm{H}$ NMR: $\left(400 \mathrm{MHz}, \mathrm{CDCl}_{3}\right)$

$7.99(\mathrm{~d}, J=8.8 \mathrm{~Hz}, 2 \mathrm{H}) ; 7.61(\mathrm{~d}, J=8.8 \mathrm{~Hz}, 2 \mathrm{H}) ; 5.48(\mathrm{t}, J=4.2 \mathrm{~Hz}, 1 \mathrm{H})$;

$4.38(\mathrm{q}, J=7.2 \mathrm{~Hz}, 2 \mathrm{H}) ; 4.19(\mathrm{t}, J=5.2 \mathrm{~Hz}, 2 \mathrm{H}) ; 2.24(\mathrm{~m}, 2 \mathrm{H}) ; 1.93(\mathrm{~m}, 2 \mathrm{H})$; $1.40(\mathrm{t}, J=7.2 \mathrm{~Hz}, 3 \mathrm{H})$

${ }^{13} \mathrm{C} \mathrm{NMR:}\left(100 \mathrm{MHz}, \mathrm{CDCl}_{3}\right)$

$166.9 ; 151.4 ; 140.7 ; 129.8 ; 127.6 ; 124.4 ; 100.1 ; 66.9 ; 61.2 ; 22.7 ; 21.3 ; 14.7$

MS: $\quad(\mathrm{EI}+)$ calculated for $\mathrm{C}_{14} \mathrm{H}_{16} \mathrm{O}_{3} 232.1099$, found $\mathrm{m} / \mathrm{z}=232.1105$

TLC: $\quad \mathrm{R}_{\mathrm{f}} 0.42\left(\mathrm{SiO}_{2}\right.$, hexane / EtOAc, $\left.20 / 1\right)$

GC: $\quad t_{\mathrm{R}} \mathbf{3 b}, 11.60 \mathrm{~min}\left(\mathrm{HP} 5890\right.$; injector $250^{\circ} \mathrm{C}$, column gradient $110^{\circ} \mathrm{C}$ for $3 \mathrm{~min}$, $25^{\circ} \mathrm{C}$ per min to $200^{\circ} \mathrm{C}, 200^{\circ} \mathrm{C}$ for $8 \mathrm{~min} ; 8.4 \mathrm{psi}$ ) 


\section{Reaction of Ethyl-3-bromobenzoate $2 \mathrm{c}$ with $\mathbf{1}$}

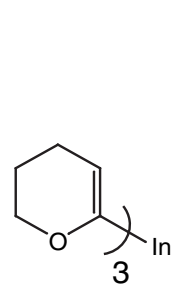

1

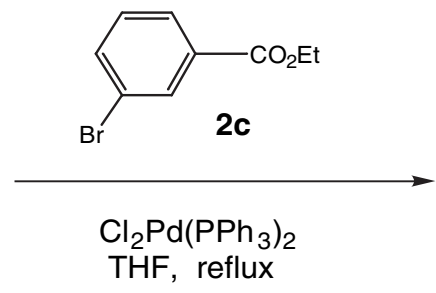

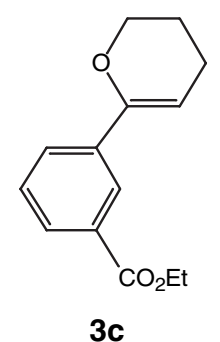

3c

Following the general procedure, a $0.25 \mathrm{M}$ THF solution of $1(1.32 \mathrm{~mL}, 0.33$ mmol, 0.33 equiv) was added to a refluxing solution of dry THF $(1.5 \mathrm{~mL})$, ethyl-3bromobenzoate $2 \mathrm{c}(0.160 \mathrm{~mL}, 1 \mathrm{mmol})$ and $\left(\mathrm{PPh}_{3}\right)_{2} \mathrm{PdCl}_{2}(7 \mathrm{mg}, 0.01 \mathrm{mmol})$. The resulting mixture was refluxed for $1 \mathrm{~h}$ under dry $\mathrm{N}_{2}$. The progress of the reaction was monitored by TLC and GC/MS. Another $2 \mathrm{~mol} \%\left(\mathrm{PPh}_{3}\right)_{2} \mathrm{PdCl}_{2}(14 \mathrm{mg}, 0.02 \mathrm{mmol})$ was added and the reaction was refluxed for another hour. Another portion of $1(2.64 \mathrm{~mL}$, 0.66 mmol, 0.66 equiv) was added and the mixture was again refluxed for $1 \mathrm{~h}$ and monitored by TLC and GC/MS. The reaction was then quenched by the addition of a few drops of methyl alcohol. The suspension was filtered through a short plug of celite. A few drops of $\mathrm{NEt}_{3}$ in hexane were added to a silica-gel slurry before loading the column for chromatography. Purification of the residue $\left(\mathrm{SiO}_{2}\right.$, hexane / EtOAc, $\left.20 / 1\right)$ gave 3c as a yellow oil ( $25.3 \mathrm{mg}, 0.109 \mathrm{mmol}, 10.9 \%$ isolated yield).

Data for 3c:

${ }^{1} \mathrm{H}$ NMR: $\left(400 \mathrm{MHz}, \mathrm{CDCl}_{3}\right)$

$8.23(\mathrm{t}, J=1.6 \mathrm{~Hz}, 1 \mathrm{H}) ; 7.95(\mathrm{~d}, J=5.2 \mathrm{~Hz}, 1 \mathrm{H}) ; 7.75(\mathrm{~d}, J=3.2 \mathrm{~Hz}, 1 \mathrm{H}) ;$

$7.39(\mathrm{t}, J=7.6 \mathrm{~Hz}, 1 \mathrm{H}) ; 5.44(\mathrm{t}, J=4.0 \mathrm{~Hz}, 1 \mathrm{H}) ; 4.37(\mathrm{q}, J=6.8 \mathrm{~Hz}, 2 \mathrm{H})$;

$4.21(\mathrm{t}, J=5.2 \mathrm{~Hz}, 2 \mathrm{H}) ; 2.24(\mathrm{~m}, 2 \mathrm{H}) ; 1.94(\mathrm{~m}, 2 \mathrm{H}) ; 1.40(\mathrm{t}, J=7.2 \mathrm{~Hz}, 3 \mathrm{H})$

${ }^{13} \mathrm{C}$ NMR: $\left(100 \mathrm{MHz}, \mathrm{CDCl}_{3}\right)$

$167.0 ; 151.1 ; 136.9 ; 129.1 ; 129.0 ; 128.5 ; 125.9 ; 98.6 ; 66.9 ; 61.3 ; 22.7 ; 21.2$; 14.7

MS: (low resolution): calculated for $\mathrm{C}_{14} \mathrm{H}_{16} \mathrm{O}_{3} 232$, found $\mathrm{m} / \mathrm{z}=232$.

TLC: $\quad \mathrm{R}_{\mathrm{f}} 0.64\left(\mathrm{SiO}_{2}\right.$, hexane / EtOAc, $\left.20 / 1\right)$

GC: $\quad t_{\mathrm{R}} 3 \mathbf{c}, 14.51 \mathrm{~min}\left(\mathrm{HP} 5890\right.$; injector $250^{\circ} \mathrm{C}$, column gradient $50^{\circ} \mathrm{C}$ for $4 \mathrm{~min}$, $25^{\circ} \mathrm{C}$ per min to $200^{\circ} \mathrm{C}, 200^{\circ} \mathrm{C}$ for $8 \mathrm{~min} ; 8.4 \mathrm{psi}$ ) 
Reaction of Ethyl-2-bromobenzoate 2d with $\mathbf{1}$
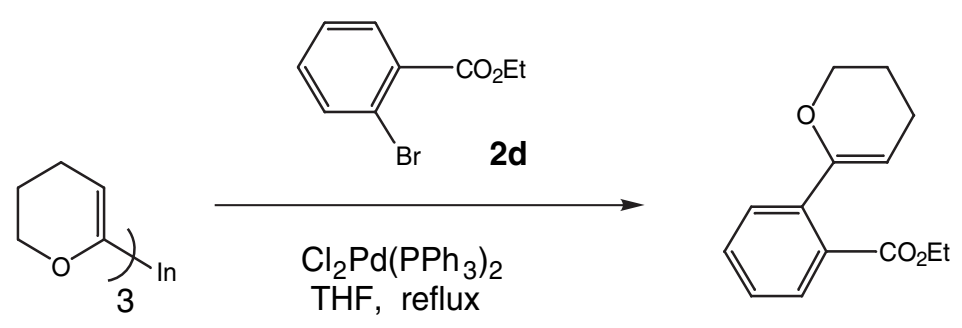

1

$3 d$

Following the general procedure, a $0.25 \mathrm{M}$ THF solution of $1(1.32 \mathrm{~mL}, 0.33$ mmol, 0.33 equiv) was added to a refluxing solution of dry THF (1.5 mL), ethyl-2bromobenzoate $2 \mathbf{d}(0.159 \mathrm{~mL}, 0.9 \mathrm{mmol})$ and $\left(\mathrm{PPh}_{3}\right)_{2} \mathrm{PdCl}_{2}(7 \mathrm{mg}, 0.01 \mathrm{mmol})$. The resulting mixture was refluxed for $3 \mathrm{~h}$ under dry $\mathrm{N}_{2}$. The progress of the reaction was monitored by TLC and GC/MS every hour. The reaction was then quenched by the addition of a few drops of methyl alcohol. The suspension was filtered through a short plug of celite. A few drops of $\mathrm{NEt}_{3}$ in hexane were added to a silica-gel slurry before loading the column for chromatography. Purification of the residue $\left(\mathrm{SiO}_{2}\right.$, hexane / EtOAc, 20 / 1) gave 3d as a yellow oil (119.8 mg, $0.515 \mathrm{mmol}, 57.2 \%$ isolated yield).

Data for 3d:

${ }^{1} \mathrm{H}$ NMR: $\left(400 \mathrm{MHz}, \mathrm{CDCl}_{3}\right)$

$7.58(\mathrm{~d}, J=8.0 \mathrm{~Hz}, 1 \mathrm{H}) ; 7.29-7.40(\mathrm{~m}, 3 \mathrm{H}) ; 5.06(\mathrm{t}, J=4.0 \mathrm{~Hz}, 1 \mathrm{H}) ; 4.34(\mathrm{q}$, $J=7.2 \mathrm{~Hz}, 2 \mathrm{H}) ; 4.08(\mathrm{dd}, J=5.6,5.2 \mathrm{~Hz}, 2 \mathrm{H}) ; 2.20(\mathrm{~m}, 2 \mathrm{H}) ; 1.90(\mathrm{~m}, 2 \mathrm{H})$; $1.37(\mathrm{t}, J=7.2 \mathrm{~Hz}, 3 \mathrm{H})$

${ }^{13} \mathrm{C}$ NMR: $\left(100 \mathrm{MHz}, \mathrm{CDCl}_{3}\right)$ $169.5 ; 153.1 ; 137.1 ; 132.8 ; 130.9 ; 129.1 ; 128.7 ; 127.9 ; 100.5 ; 67.0 ; 62.0 ;$ $22.6 ; 21.2 ; 14.7$

MS: $\quad$ (low resolution): calculated for $\mathrm{C}_{14} \mathrm{H}_{16} \mathrm{O}_{3} 232$, found $\mathrm{m} / \mathrm{z}=232$

TLC: $\quad \mathrm{R}_{\mathrm{f}} 0.50\left(\mathrm{SiO}_{2}\right.$, hexane / EtOAc, $\left.10 / 1\right)$

GC: $\quad t_{R}$ 3d, 8.11 min (HP5890; injector $250{ }^{\circ} \mathrm{C}$, column gradient $110{ }^{\circ} \mathrm{C}$ for $3 \mathrm{~min}$, $25{ }^{\circ} \mathrm{C}$ per min to $200{ }^{\circ} \mathrm{C}, 200{ }^{\circ} \mathrm{C}$ for $8 \mathrm{~min}$; 8.4 psi) 


\section{$\underline{\text { Reaction of 1-bromo-4-chlorobenzene 2e with } \mathbf{1}}$}

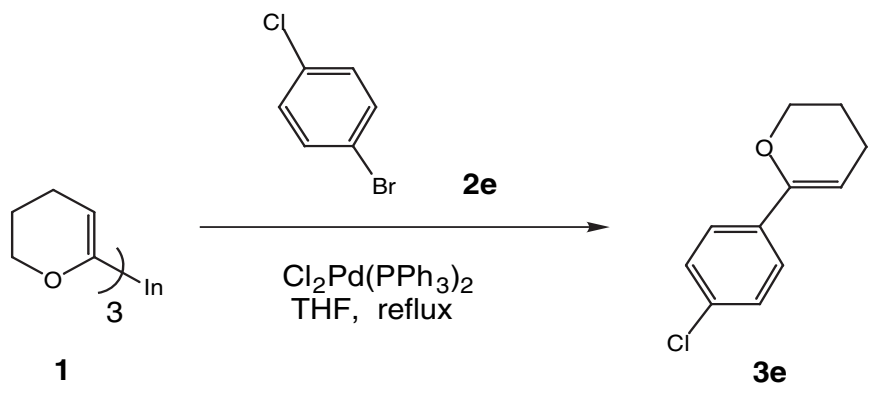

Following the general procedure, a $0.25 \mathrm{M}$ THF solution of $1(1.32 \mathrm{~mL}, 0.33$ mmol, 0.33 equiv) was added to a refluxing solution of dry THF $(1.5 \mathrm{~mL}), 1$-bromo-4chlorobenzene $2 \mathrm{e}(0.172 \mathrm{~g}, 0.9 \mathrm{mmol})$ and $\left(\mathrm{PPh}_{3}\right)_{2} \mathrm{PdCl}_{2}(7 \mathrm{mg}, 0.01 \mathrm{mmol})$. The resulting mixture was refluxed for $1 \mathrm{~h}$ under dry $\mathrm{N}_{2}$. The progress of the reaction was monitored by TLC and GC/MS. The reaction was then quenched by the addition of a few drops of methyl alcohol. The suspension was filtered through a short plug of celite. Purification of the residue by column chromatography $\left(\mathrm{SiO}_{2}\right.$, hexane) gave $\mathbf{3 e}$ as a colorless oil (171.9 $\mathrm{mg}, 0.882 \mathrm{mmol}, 98.0 \%$ yield).

Data for 3e:

${ }^{1} \mathrm{H}$ NMR: $\left(400 \mathrm{MHz}, \mathrm{CDCl}_{3}\right)$

$7.49(\mathrm{~d}, J=8.8 \mathrm{~Hz}, 2 \mathrm{H}) ; 7.29(\mathrm{~d}, J=8.4 \mathrm{~Hz}, 2 \mathrm{H}) ; 5.34(\mathrm{t}, J=4.2 \mathrm{~Hz}, 1 \mathrm{H}) ;$

$4.18(\mathrm{t}, J=5.2 \mathrm{~Hz}, 2 \mathrm{H}) ; 2.23(\mathrm{~m}, 2 \mathrm{H}) ; 1.92(\mathrm{~m}, 2 \mathrm{H})$

${ }^{13} \mathrm{C} \mathrm{NMR:}\left(100 \mathrm{MHz}, \mathrm{CDCl}_{3}\right)$

$151.3 ; 135.1 ; 133.2 ; 130.6 ; 128.6 ; 126.0 ; 120.7 ; 98.2 ; 66.9 ; 22.7 ; 21.2$

MS: $\quad$ (low res): calculated for $\mathrm{C}_{11} \mathrm{H}_{11} \mathrm{ClO} 194, \mathrm{~m} / \mathrm{z}=195$

TLC: $\quad \mathrm{R}_{\mathrm{f}} 0.68\left(\mathrm{SiO}_{2}\right.$, hexane $)$

GC: $\quad t_{\mathrm{R}} 3 \mathbf{e}, 7.63 \mathrm{~min}\left(\mathrm{HP} 5890\right.$; injector $250^{\circ} \mathrm{C}$, column gradient $110^{\circ} \mathrm{C}$ for $3 \mathrm{~min}$, $25^{\circ} \mathrm{C}$ per min to $200^{\circ} \mathrm{C}, 200^{\circ} \mathrm{C}$ for $8 \mathrm{~min} ; 8.4 \mathrm{psi}$ ) 


\section{Reaction of 1-bromo-2-nitrobenzene $2 \mathbf{f}$ with $\mathbf{1}$}

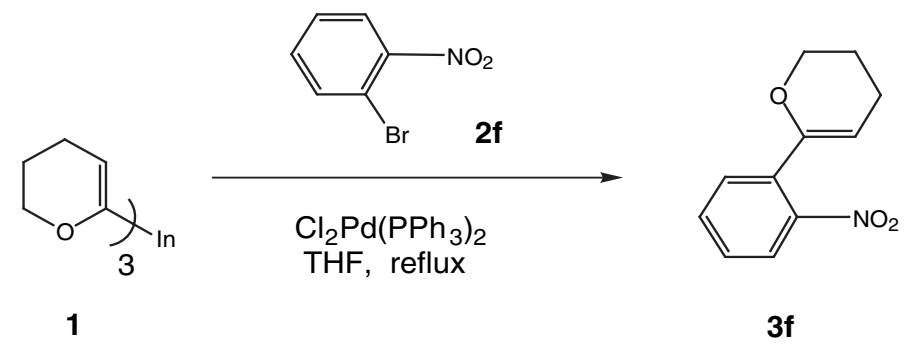

Following the general procedure, a $0.25 \mathrm{M}$ THF solution of $1(1.32 \mathrm{~mL}, 0.33$ mmol, 0.33 equiv) was added to a refluxing solution of dry THF (1.5 mL), 1-bromo-2nitrobenzene $2 \mathbf{f}(0.202 \mathrm{~g}, 1 \mathrm{mmol})$ and $\left(\mathrm{PPh}_{3}\right)_{2} \mathrm{PdCl}_{2}(21 \mathrm{mg}, 0.03 \mathrm{mmol})$. The resulting mixture was refluxed for $1 \mathrm{~h}$ under dry $\mathrm{N}_{2}$. The progress of the reaction was monitored by TLC and GC/MS after $1 \mathrm{~h}$ and $2 \mathrm{~h}$. Additional 1 (2.64 mL, $0.66 \mathrm{mmol}, 0.66$ equiv) and another $2 \mathrm{~mol} \%\left(\mathrm{PPh}_{3}\right)_{2} \mathrm{PdCl}_{2}(14 \mathrm{mg}, 0.02 \mathrm{mmol})$ were added. The mixture was again refluxed for $1 \mathrm{~h}$ and monitored by TLC and GC/MS. The reaction was then quenched by the addition of a few drops of methyl alcohol. The suspension was filtered through a short plug of celite. A few drops of $\mathrm{NEt}_{3}$ in hexane were added to a silica-gel slurry before loading the column for chromatography. Purification of the residue $\left(\mathrm{SiO}_{2}\right.$, hexane / $\mathrm{Et}_{2} \mathrm{O}$, 20 / 1) gave 3f as a yellow oil (109 $\mathrm{mg}, 0.530 \mathrm{mmol}, 53.0 \%$ isolated yield).

Data for 3f:

H NMR: $\left(400 \mathrm{MHz}, \mathrm{CDCl}_{3}\right)$

$7.71(\mathrm{~d}, J=8.0 \mathrm{~Hz}, 1 \mathrm{H}) ; 7.53-7.39(\mathrm{~m}, 3 \mathrm{H}) ; 5.17(\mathrm{t}, J=4.0 \mathrm{~Hz}, 1 \mathrm{H}) ; 4.06(\mathrm{t}$, $J=5.2 \mathrm{~Hz}, 2 \mathrm{H}) ; 2.22(\mathrm{~m}, 2 \mathrm{H}) ; 1.91(\mathrm{~m}, 2 \mathrm{H})$.

${ }^{13} \mathrm{C} \mathrm{NMR:}\left(100 \mathrm{MHz}, \mathrm{CDCl}_{3}\right)$

$150.8 ; 132.5 ; 132.0 ; 130.5 ; 129.2 ; 124.2 ; 102.6 ; 67.4 ; 55.7 ; 22.4 ; 21.1$

MS: $\quad(\mathrm{EI}+)$ calculated for $\mathrm{C}_{11} \mathrm{H}_{11} \mathrm{NO}_{3} 205.0739$, found $\mathrm{m} / z=205.0732$

TLC: $\quad \mathrm{R}_{\mathrm{f}} 0.43\left(\mathrm{SiO}_{2}\right.$, hexane / $\left.\mathrm{Et}_{2} \mathrm{O}, 30 / 1\right)$

GC: $\quad t_{R}$ 3f, 11.97 min (HP5890; injector $250^{\circ} \mathrm{C}$, column gradient $50^{\circ} \mathrm{C}$ for $4 \mathrm{~min}$, $25^{\circ} \mathrm{C}$ per min to $200^{\circ} \mathrm{C}, 200^{\circ} \mathrm{C}$ for $8 \mathrm{~min} ; 8.4 \mathrm{psi}$ ) 
Reaction of 2-bromobenzaldehyde $2 \mathrm{~g}$ with 1

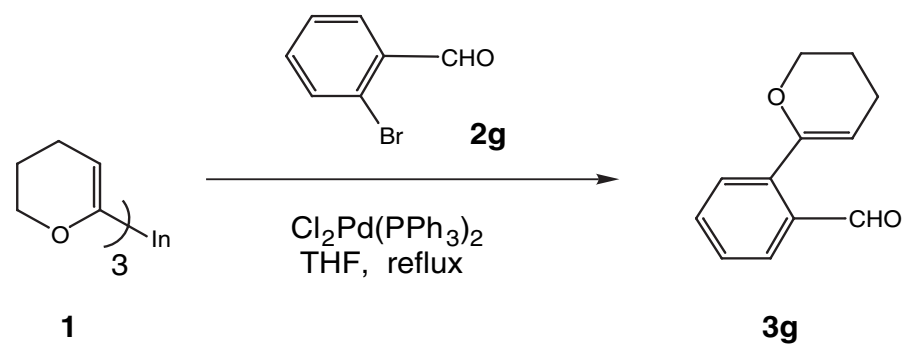

Following the general procedure, a $0.25 \mathrm{M}$ THF solution of $1(1.32 \mathrm{~mL}, 0.33$ mmol, 0.33 equiv) was added to a refluxing solution of dry THF $(1.5 \mathrm{~mL}), 2$ bromobenzaldehyde $2 \mathrm{~g}(0.117 \mathrm{~mL}, 1 \mathrm{mmol})$ and $\left(\mathrm{PPh}_{3}\right)_{2} \mathrm{PdCl}_{2}(7 \mathrm{mg}, 0.01 \mathrm{mmol})$. The resulting mixture was refluxed for $1 \mathrm{~h}$ under dry $\mathrm{N}_{2}$. The progress of the reaction was monitored by TLC and GC/MS. Additional $1(2.64 \mathrm{~mL}, 0.66 \mathrm{mmol}, 0.66$ equiv) and another $2 \mathrm{~mol} \%\left(\mathrm{PPh}_{3}\right)_{2} \mathrm{PdCl}_{2}(14 \mathrm{mg}, 0.02 \mathrm{mmol})$ were added. The mixture was again refluxed for $1 \mathrm{~h}$ and monitored by TLC and GC/MS. The reaction was then quenched by the addition of a few drops of methyl alcohol. The suspension was filtered through a short plug of celite. A few drops of $\mathrm{NEt}_{3}$ in hexane were added to a silica-gel slurry before loading the column for chromatography. Purification of the residue $\left(\mathrm{SiO}_{2}\right.$, hexane / EtOAc, 20 / 1) gave $\mathbf{3 g}$ as a yellow oil (44.8 $\mathrm{mg}, 0.239 \mathrm{mmol}, 23.9 \%$ isolated yield).

Data for 3g:

H NMR: $\left(400 \mathrm{MHz}, \mathrm{CDCl}_{3}\right)$

$10.27(\mathrm{~s}, 1 \mathrm{H}) ; 7.90(\mathrm{~d}, J=4.0 \mathrm{~Hz}) ; 7.57-7.41(\mathrm{~m}, 3 \mathrm{H}) ; 5.01(\mathrm{t}, J=4.0 \mathrm{~Hz}$, $1 \mathrm{H}) ; 4.21(\mathrm{t}, J=6.0 \mathrm{~Hz}, 2 \mathrm{H}) ; 2.26(\mathrm{~m}, 2 \mathrm{H}) ; 1.97(\mathrm{~m}, 2 \mathrm{H})$

${ }^{13} \mathrm{C} \mathrm{NMR:}\left(100 \mathrm{MHz}, \mathrm{CDCl}_{3}\right)$

$192.7 ; 150.8 ; 140.9 ; 134.6 ; 133.6 ; 129.4 ; 128.8 ; 127.7 ; 104.8 ; 67.1 ; 22.5 ; 21.3$

MS: $\quad$ (EI+) calculated for $\mathrm{C}_{12} \mathrm{H}_{12} \mathrm{O}_{2} 188.0837$, found $\mathrm{m} / \mathrm{z}=188.0845$

TLC: $\quad \mathrm{R}_{\mathrm{f}} 0.49\left(\mathrm{SiO}_{2}\right.$, hexane / EtOAc, $\left.20 / 1\right)$

GC: $\quad \mathrm{t}_{\mathrm{R}} \mathbf{3 g}, 8.97 \mathrm{~min}\left(\mathrm{HP} 5890\right.$; injector $250^{\circ} \mathrm{C}$, column gradient $110^{\circ} \mathrm{C}$ for $3 \mathrm{~min}$, $25^{\circ} \mathrm{C}$ per min to $200^{\circ} \mathrm{C}, 200^{\circ} \mathrm{C}$ for $8 \mathrm{~min} ; 8.4 \mathrm{psi}$ ) 


\section{$\underline{\text { Reaction of 1-bromonaphthalene } 2 \mathrm{~h} \text { with } \mathbf{1}}$}

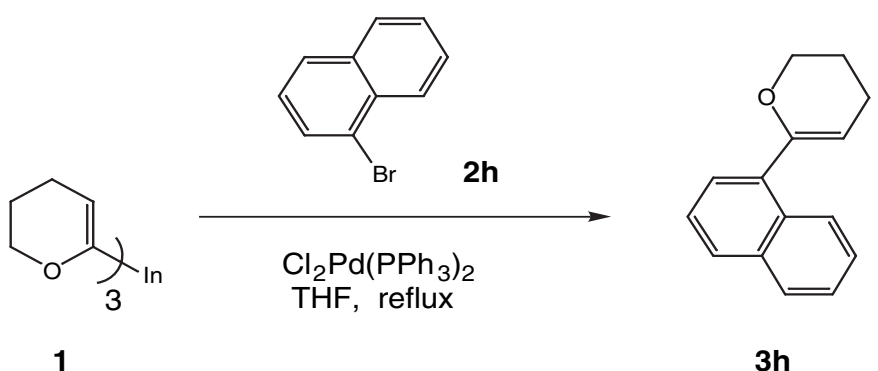

Following the general procedure, a $0.25 \mathrm{M}$ THF solution of $1(1.32 \mathrm{~mL}, 0.33$ mmol, 0.33 equiv) was added to a refluxing solution of dry THF $(1.5 \mathrm{~mL}), 1$ bromonaphthalene $2 \mathbf{h}(0.125 \mathrm{~mL}, 0.9 \mathrm{mmol})$ and $\left(\mathrm{PPh}_{3}\right)_{2} \mathrm{PdCl}_{2}(21 \mathrm{mg}, 0.03 \mathrm{mmol})$. The resulting mixture was refluxed for $1 \mathrm{~h}$ under dry $\mathrm{N}_{2}$. The progress of the reaction was monitored by TLC and GC/MS. Additional $1(2.64 \mathrm{~mL}, 0.66 \mathrm{mmol}, 0.66$ equiv) and another $2 \mathrm{~mol} \%\left(\mathrm{PPh}_{3}\right)_{2} \mathrm{PdCl}_{2}(14 \mathrm{mg}, 0.02 \mathrm{mmol})$ were added. The mixture was again refluxed for $1 \mathrm{~h}$ and monitored by TLC and GC/MS. The reaction was then quenched by the addition of a few drops of methyl alcohol. The suspension was filtered through a short plug of celite. A few drops of $\mathrm{NEt}_{3}$ in hexane were added to a silica-gel slurry before loading the column for chromatography. Purification of the residue $\left(\mathrm{SiO}_{2}\right.$, hexane) gave $\mathbf{3 h}$ as a yellow oil.

Data for 3h:

H NMR: $\left(400 \mathrm{MHz}, \mathrm{CDCl}_{3}\right)$

$8.19(\mathrm{t}, J=10.0 \mathrm{~Hz}, 1 \mathrm{H}) ; 7.83(\mathrm{~m}, 2 \mathrm{H}) ; 7.53-7.42(\mathrm{~m}, 4 \mathrm{H}) ; 5.06(\mathrm{t}, J=4.0 \mathrm{~Hz}$, $1 \mathrm{H}) ; 4.31(\mathrm{t}, J=5.2 \mathrm{~Hz}, 2 \mathrm{H}) ; 2.30(\mathrm{~m}, 2 \mathrm{H}) ; 2.06(\mathrm{~m}, 2 \mathrm{H})$.

${ }^{13} \mathrm{C} \mathrm{NMR:}\left(100 \mathrm{MHz}, \mathrm{CDCl}_{3}\right)$

$129.0 ; 128.7 ; 128.5 ; 128.3 ; 126.8 ; 126.3 ; 126.1 ; 125.5 ; 124.8 ; 102.2 ; 67.0 ;$ $62.9 ; 22.9 ; 21.3 ; 21.1$

MS: (low resolution): calculated for $\mathrm{C}_{15} \mathrm{H}_{14} \mathrm{O} \quad 210$, found $\mathrm{m} / \mathrm{z}=210$

TLC: $\quad \mathrm{R}_{\mathrm{f}} 0.44\left(\mathrm{SiO}_{2}\right.$, hexane $)$

GC: $\quad t_{\mathrm{R}} 3 \mathrm{~h}, 10.70 \mathrm{~min}\left(\mathrm{HP} 5890\right.$; injector $250^{\circ} \mathrm{C}$, column gradient $110^{\circ} \mathrm{C}$ for $3 \mathrm{~min}$, $25^{\circ} \mathrm{C}$ per min to $200^{\circ} \mathrm{C}, 200^{\circ} \mathrm{C}$ for $8 \mathrm{~min} ; 8.4 \mathrm{psi}$ ) 


\section{$\underline{\text { Reaction of 4-acetoxybromobenzene } 2 \text { I with } \mathbf{1}}$}

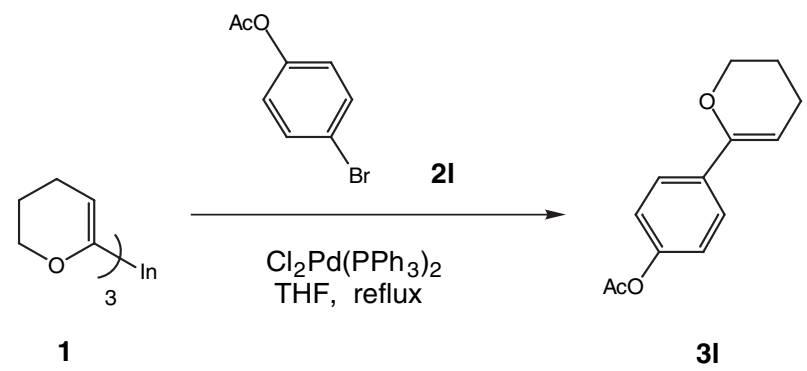

Following the general procedure, a $0.25 \mathrm{M}$ THF solution of $1(2.64 \mathrm{~mL}, 0.66$ mmol, 0.66 equiv) was added to a refluxing solution of dry THF $(1.5 \mathrm{~mL}), 4-$ acetoxybromobenzene $2 \mathbf{2 l}(0.193 \mathrm{~g}, 0.9 \mathrm{mmol})$ and $\left(\mathrm{PPh}_{3}\right)_{2} \mathrm{PdCl}_{2}(7 \mathrm{mg}, 0.01 \mathrm{mmol})$. The resulting mixture was refluxed for $1 \mathrm{~h}$ under dry $\mathrm{N}_{2}$. The progress of the reaction was monitored by TLC and GC/MS. The reaction was then quenched by the addition of a few drops of methyl alcohol. The suspension was filtered through a short plug of celite. Purification of the residue by column chromatography $\left(\mathrm{SiO}_{2}\right.$, hexane / EtOAc, $\left.20 / 1\right)$ gave $3 \mathrm{l}$ as a colorless oil (16.9 $\mathrm{mg}, 0.0773 \mathrm{mmol}, 8.6 \%$ isolated yield).

\section{Data for 31:}

${ }^{1} \mathrm{H}$ NMR: $\left(400 \mathrm{MHz}, \mathrm{CDCl}_{3}\right)$

$7.56(\mathrm{~d}, J=8.8 \mathrm{~Hz}, 2 \mathrm{H}) ; 7.06(\mathrm{~d}, J=8.8 \mathrm{~Hz}, 2 \mathrm{H}) ; 5.31(\mathrm{t}, J=4.0 \mathrm{~Hz}, 1 \mathrm{H})$;

$4.18(\mathrm{dd}, J=4.8,5.0 \mathrm{~Hz}, 2 \mathrm{H}) ; 2.31(\mathrm{~s}, 3 \mathrm{H}) ; 2.22(\mathrm{~m}, 2 \mathrm{H}) ; 1.92(\mathrm{~m}, 2 \mathrm{H})$.

${ }^{13} \mathrm{C} \mathrm{NMR:}\left(100 \mathrm{MHz}, \mathrm{CDCl}_{3}\right)$

$178.0 ; 169.5 ; 151.5 ; 134.4 ; 131.0 ; 125.8 ; 121.5 ; 107.5 ; 97.8 ; 66.9 ; 22.8 ; 21.5$; 21.2

MS: $\quad$ (EI+) calculated for $\mathrm{C}_{13} \mathrm{H}_{14} \mathrm{O}_{3} 218.0943$, found $\mathrm{m} / \mathrm{z}=218.0945$

TLC: $\quad \mathrm{R}_{\mathrm{f}} 0.31\left(\mathrm{SiO}_{2}\right.$, hexane / EtOAc, 20 / 1)

GC: $\quad \mathrm{t}_{\mathrm{R}}$ 3l, $9.58 \mathrm{~min}\left(\mathrm{HP} 5890\right.$; injector $250^{\circ} \mathrm{C}$, column gradient $110^{\circ} \mathrm{C}$ for $3 \mathrm{~min}$, $25^{\circ} \mathrm{C}$ per min to $200^{\circ} \mathrm{C}, 200^{\circ} \mathrm{C}$ for $\left.8 \mathrm{~min} ; 8.4 \mathrm{psi}\right)$ 


\section{$\underline{\text { Reaction of Iodobenzene } \mathbf{2 m} \text { with } \mathbf{1}}$}

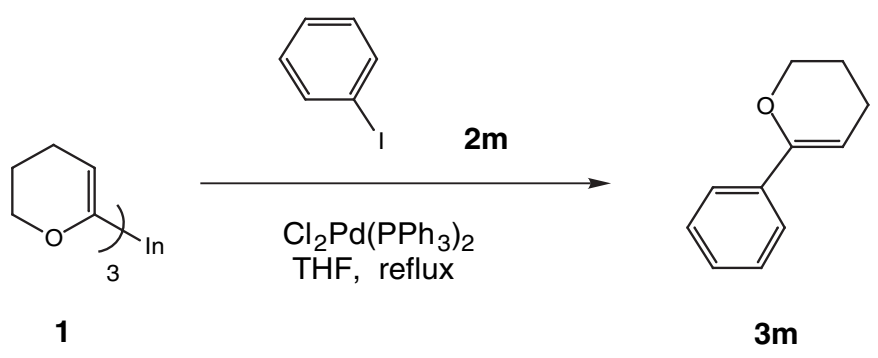

Following the general procedure, a $0.25 \mathrm{M}$ THF solution of $1(1.32 \mathrm{~mL}, 0.33$ mmol, 0.33 equiv) was added to a refluxing solution of dry THF $(1.5 \mathrm{~mL})$, iodobenzene $2 \mathrm{~m}(0.101 \mathrm{~mL}, 0.9 \mathrm{mmol})$ and $\left(\mathrm{PPh}_{3}\right)_{2} \mathrm{PdCl}_{2}(14 \mathrm{mg}, 0.02 \mathrm{mmol})$. The resulting mixture was refluxed for $1 \mathrm{~h}$ under dry $\mathrm{N}_{2}$. The progress of the reaction was monitored by TLC and GC/MS. The reaction was then quenched by the addition of a few drops of methyl alcohol. The suspension was filtered through a short plug of celite filter aid. Purification of the residue by column chromatography $\left(\mathrm{SiO}_{2}\right.$, hexane / $\left.\mathrm{Et}_{2} \mathrm{O}, 15 / 1\right)$ gave $\mathbf{3} \mathbf{m}$ as a yellow oil (135.1 mg, $0.842 \mathrm{mmol}, 93.5 \%$ yield).

Data for 3m:

${ }^{1} \mathrm{H}$ NMR: $\left(400 \mathrm{MHz}, \mathrm{CDCl}_{3}\right)$

$7.59(\mathrm{~d}, J=8.0 \mathrm{~Hz}, 2 \mathrm{H}) ; 7.23-7.40(\mathrm{~m}, 3 \mathrm{H}) ; 5.38(\mathrm{t}, J=4.0 \mathrm{~Hz}, 1 \mathrm{H}) ; 4.22(\mathrm{t}$, $J=5.2 \mathrm{~Hz}, 2 \mathrm{H}) ; 2.26(\mathrm{~m}, 2 \mathrm{H}) ; 1.95(\mathrm{~m}, 2 \mathrm{H})$.

${ }^{13} \mathrm{C} \mathrm{NMR:}\left(100 \mathrm{MHz}, \mathrm{CDCl}_{3}\right)$

$152.2 ; 137.9 ; 136.7 ; 130.6 ; 128.5 ; 128.1 ; 124.8 ; 97.2 ; 66.9 ; 22.9 ; 21.3$

MS: $\quad\left(\right.$ EI+) calculated for $\mathrm{C}_{11} \mathrm{H}_{12} \mathrm{O} 160.0888$, found $\mathrm{m} / \mathrm{z}=160.0881$

TLC: $\quad \mathrm{R}_{\mathrm{f}} 0.65\left(\mathrm{SiO}_{2}\right.$, hexane)

GC: $\quad t_{\mathrm{R}} 3 \mathrm{~m}, 6.33 \mathrm{~min}\left(\mathrm{HP} 5890\right.$; injector $250^{\circ} \mathrm{C}$, column gradient $110^{\circ} \mathrm{C}$ for $3 \mathrm{~min}$, $25^{\circ} \mathrm{C}$ per min to $200^{\circ} \mathrm{C}, 200^{\circ} \mathrm{C}$ for $8 \mathrm{~min} ; 8.4 \mathrm{psi}$ ) 
Reaction of 4-iodotoluene $2 n$ with 1

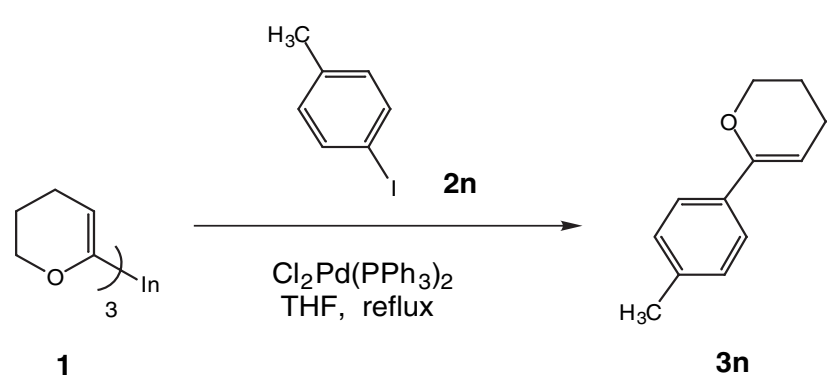

Following the general procedure, a $0.25 \mathrm{M}$ THF solution of $1(1.32 \mathrm{~mL}, 0.33$ mmol, 0.33 equiv) was added to a refluxing solution of dry THF $(1.5 \mathrm{~mL})$, 4-iodotoluene 2n $(0.196 \mathrm{~g}, 0.9 \mathrm{mmol})$ and $\left(\mathrm{PPh}_{3}\right)_{2} \mathrm{PdCl}_{2}(21 \mathrm{mg}, 0.03 \mathrm{mmol})$. The resulting mixture was refluxed for $1 \mathrm{~h}$ under dry $\mathrm{N}_{2}$. The progress of the reaction was monitored by TLC and GC/MS. Additional 1 (2.64 mL, $0.66 \mathrm{mmol}, 0.66$ equiv) was added. The mixture was again refluxed for $1 \mathrm{~h}$ and monitored by TLC and GC/MS. The reaction was then quenched by the addition of a few drops of methyl alcohol. The suspension was filtered through a short plug of celite. Purification of the residue by column chromatography $\left(\mathrm{SiO}_{2}\right.$, hexane $\left./ \mathrm{Et}_{2} \mathrm{O}, 50 / 1\right)$ gave 3n as a yellow oil $(75.4 \mathrm{mg}, 0.432 \mathrm{mmol}, 48.0 \%$ isolated yield).

Data for 3n:

${ }^{1} \mathrm{H}$ NMR: $\left(400 \mathrm{MHz}, \mathrm{CDCl}_{3}\right)$

$7.45(\mathrm{~d}, J=8.4 \mathrm{~Hz}, 2 \mathrm{H}) ; 7.14(\mathrm{~d}, J=8.0 \mathrm{~Hz}, 2 \mathrm{H}) ; 5.30(\mathrm{t}, J=4.0 \mathrm{~Hz}, 1 \mathrm{H})$;

$4.19(\mathrm{t}, J=5.2 \mathrm{~Hz}, 2 \mathrm{H}) ; 2.36(\mathrm{~s}, 3 \mathrm{H}) ; 2.23(\mathrm{~m}, 2 \mathrm{H}) ; 1.94(\mathrm{~m}, 2 \mathrm{H})$

${ }^{13} \mathrm{C}$ NMR: $\left(100 \mathrm{MHz}, \mathrm{CDCl}_{3}\right)$

$171.0 ; 137.8 ; 133.9 ; 129.2 ; 128.7 ; 124.7 ; 96.8 ; 66.8 ; 32.3 ; 22.9 ; 21.3 ; 14.5$

MS: $\quad(E I+)$ calculated for $\mathrm{C}_{12} \mathrm{H}_{14} \mathrm{O} 174.1045$, found $\mathrm{m} / \mathrm{z}=174.1049$

TLC: $\quad \mathrm{R}_{\mathrm{f}} 0.70\left(\mathrm{SiO}_{2}\right.$, hexane / EtOAc, $\left.30 / 1\right)$

GC: $\quad t_{\mathrm{R}} 3 \mathbf{n}, 10.63 \mathrm{~min}$ (HP5890; injector $250^{\circ} \mathrm{C}$, column gradient $50^{\circ} \mathrm{C}$ for $4 \mathrm{~min}$, $25^{\circ} \mathrm{C}$ per min to $200^{\circ} \mathrm{C}, 200^{\circ} \mathrm{C}$ for $8 \mathrm{~min} ; 8.4 \mathrm{psi}$ ) 


\section{$\underline{\text { Reaction of 2-iodotoluene } 20 \text { with } 1}$}

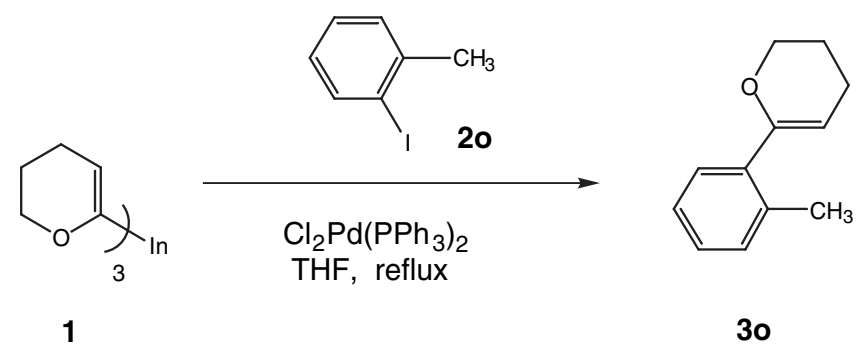

Following the general procedure, a $0.25 \mathrm{M}$ THF solution of $1(1.32 \mathrm{~mL}, 0.33$ mmol, 0.33 equiv) was added to a refluxing solution of dry THF $(1.5 \mathrm{~mL}), 2$-iodotoluene $20(0.115 \mathrm{~mL}, 0.9 \mathrm{mmol})$ and $\left(\mathrm{PPh}_{3}\right)_{2} \mathrm{PdCl}_{2}(21 \mathrm{mg}, 0.03 \mathrm{mmol})$. The resulting mixture was refluxed for $1 \mathrm{~h}$ under dry $\mathrm{N}_{2}$. The progress of the reaction was monitored by TLC and GC/MS. Additional $1(2.64 \mathrm{~mL}, 0.66 \mathrm{mmol}, 0.66$ equiv) and another $2 \mathrm{~mol} \%$ $\left(\mathrm{PPh}_{3}\right)_{2} \mathrm{PdCl}_{2}(14 \mathrm{mg}, 0.02 \mathrm{mmol})$ were added because the reaction was incomplete. The mixture was again refluxed for $1 \mathrm{~h}$ and monitored by TLC and GC/MS. The reaction was then quenched by the addition of a few drops of methyl alcohol. The suspension was filtered through a short plug of celite. Purification of the residue by column chromatography $\left(\mathrm{SiO}_{2}\right.$, hexane / $\left.\mathrm{Et}_{2} \mathrm{O}, 50 / 1\right)$ gave 30 as a yellow oil (122.2 $\mathrm{mg}, 0.700$ mmol, $77.8 \%$ yield).

Data for 3o:

${ }^{1} \mathrm{H}$ NMR: $\left(400 \mathrm{MHz}, \mathrm{CDCl}_{3}\right)$

$7.34(\mathrm{~d}, J=7.6 \mathrm{~Hz}, 1 \mathrm{H}) ; 7.19-7.24(\mathrm{~m}, 3 \mathrm{H}) ; 4.89(\mathrm{t}, J=3.8 \mathrm{~Hz}, 1 \mathrm{H}) ; 4.20(\mathrm{t}, J$ $=5.2 \mathrm{~Hz}, 2 \mathrm{H}) ; 2.43(\mathrm{~s}, 3 \mathrm{H}) ; 2.24(\mathrm{~m}, 2 \mathrm{H}) ; 1.98(\mathrm{~m}, 2 \mathrm{H})$

${ }^{13} \mathrm{C}$ NMR: $\left(100 \mathrm{MHz}, \mathrm{CDCl}_{3}\right)$

$154.4 ; 137.7 ; 136.9 ; 130.6 ; 129.3 ; 128.5 ; 125.8 ; 100.7 ; 66.7 ; 22.9 ; 21.2 ; 20.6$

MS: $\quad$ (low resolution): calculated for $\mathrm{C}_{12} \mathrm{H}_{14} \mathrm{O} 174$, found $\mathrm{m} / \mathrm{z}=174$

TLC: $\quad \mathrm{R}_{\mathrm{f}} 0.63\left(\mathrm{SiO}_{2}\right.$, hexane / $\left.\mathrm{Et}_{2} \mathrm{O}, 50 / 1\right)$

GC: $\quad t_{\mathrm{R}}$ 3o, $10.09 \mathrm{~min}$ (HP5890; injector $250^{\circ} \mathrm{C}$, column gradient $50^{\circ} \mathrm{C}$ for $4 \mathrm{~min}$, $25^{\circ} \mathrm{C}$ per min to $200^{\circ} \mathrm{C}, 200^{\circ} \mathrm{C}$ for $8 \mathrm{~min} ; 8.4 \mathrm{psi}$ ) 


\section{Reaction of 4-iodoanisole $\mathbf{2 p}$ with $\mathbf{1}$}

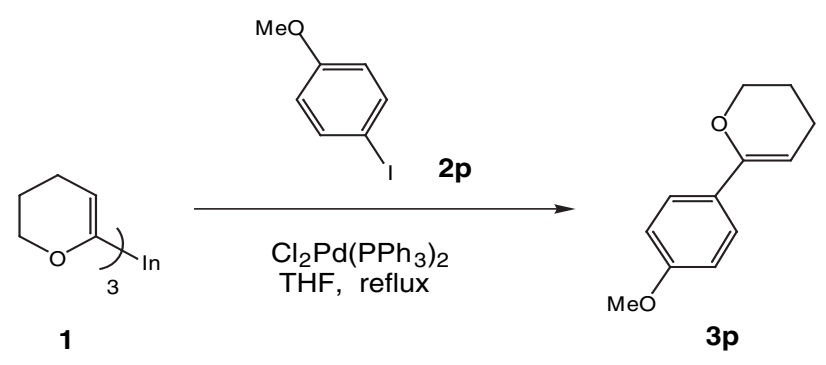

Following the general procedure, a $0.25 \mathrm{M}$ THF solution of $1(1.32 \mathrm{~mL}, 0.33$ mmol, 0.33 equiv) was added to a refluxing solution of dry THF $(1.5 \mathrm{~mL}), 4$-iodoanisole 2 p $(0.234 \mathrm{~mL}, 1 \mathrm{mmol})$ and $\left(\mathrm{PPh}_{3}\right)_{2} \mathrm{PdCl}_{2}(21 \mathrm{mg}, 0.03 \mathrm{mmol})$. The resulting mixture was refluxed for $1 \mathrm{~h}$ under dry $\mathrm{N}_{2}$. The progress of the reaction was monitored by TLC and GC/MS. Additional 1 (2.64 mL, $0.66 \mathrm{mmol}, 0.66$ equiv) was added . The mixture was again refluxed for $1 \mathrm{~h}$ and monitored by TLC and GC/MS. The reaction was then quenched by the addition of a few drops of methyl alcohol. The suspension was filtered through a short plug of celite. Purification of the residue by column chromatography $\left(\mathrm{SiO}_{2}\right.$, hexane / EtOAc, 40 / 1) gave 3p as a colorless oil (14.2 mg, $0.075 \mathrm{mmol}, 7.45 \%$ isolated yield).

Data for 3p:

${ }^{1} \mathrm{H}$ NMR: $\left(400 \mathrm{MHz}, \mathrm{CDCl}_{3}\right)$

$7.49(\mathrm{~d}, J=8.8 \mathrm{~Hz}, 2 \mathrm{H}) ; 6.86(\mathrm{~d}, J=8.8 \mathrm{~Hz}, 2 \mathrm{H}) ; 5.22(\mathrm{t}, J=4.0 \mathrm{~Hz}, 1 \mathrm{H}) ;$

$4.18(\mathrm{t}, J=5.2 \mathrm{~Hz}, 2 \mathrm{H}) ; 3.83(\mathrm{~s}, 3 \mathrm{H}) ; 2.22(\mathrm{~m}, 2 \mathrm{H}) ; 1.92(\mathrm{~m}, 2 \mathrm{H})$

${ }^{13} \mathrm{C} \mathrm{NMR:}\left(100 \mathrm{MHz}, \mathrm{CDCl}_{3}\right)$

$159.7 ; 152.0 ; 130.7 ; 129.5 ; 127.3 ; 126.1 ; 113.9 ; 96.0 ; 66.9 ; 55.7 ; 22.9 ; 21.3$

MS: $\quad(E I+)$ calculated for $\mathrm{C}_{12} \mathrm{H}_{14} \mathrm{O}_{2} 190.0994$, found $\mathrm{m} / z=190.1002$

TLC: $\quad \mathrm{R}_{\mathrm{f}} 0.43\left(\mathrm{SiO}_{2}\right.$, hexane / EtOAc, 30 / 1)

GC: $\quad t_{\mathrm{R}} 3 \mathbf{p}, 11.69 \mathrm{~min}$ (HP5890; injector $250^{\circ} \mathrm{C}$, column gradient $50^{\circ} \mathrm{C}$ for $4 \mathrm{~min}$, $25^{\circ} \mathrm{C}$ per min to $200^{\circ} \mathrm{C}, 200^{\circ} \mathrm{C}$ for $8 \mathrm{~min}$; $8.4 \mathrm{psi}$ ) 


\section{Reaction of 2-iodoanisole with 1}

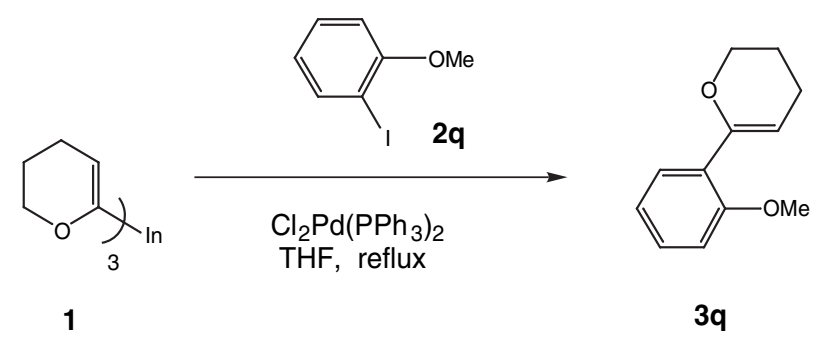

Following the general procedure, a $0.25 \mathrm{M}$ THF solution of $1(1.32 \mathrm{~mL}, 0.33$ mmol, 0.33 equiv) was added to a refluxing solution of dry THF $(1.5 \mathrm{~mL}), 2$-iodoanisole $2 \mathbf{q}(0.130 \mathrm{~mL}, 1 \mathrm{mmol})$ and $\left(\mathrm{PPh}_{3}\right)_{2} \mathrm{PdCl}_{2}(21 \mathrm{mg}, 0.03 \mathrm{mmol})$. The resulting mixture was refluxed for $1 \mathrm{~h}$ under dry $\mathrm{N}_{2}$. The progress of the reaction was monitored by TLC and GC/MS. Additional 1 (2.64 mL, $0.66 \mathrm{mmol}, 0.66$ equiv) and another $1 \mathrm{~mol} \%$ $\left(\mathrm{PPh}_{3}\right)_{2} \mathrm{PdCl}_{2}(7 \mathrm{mg}, 0.01 \mathrm{mmol})$ were added. The mixture was again refluxed for $1 \mathrm{~h}$ and monitored by TLC and GC/MS. The reaction was then quenched by the addition of a few drops of methyl alcohol. The suspension was filtered through a short plug of celite. A few drops of $\mathrm{NEt}_{3}$ in hexane were added to a silica-gel slurry before loading the column for chromatography. Purification of the residue $\left(\mathrm{SiO}_{2}\right.$, hexane / EtOAc, 40 / 1) gave 3q as a yellow oil (24.5 mg, $0.129 \mathrm{mmol} ; 12.9 \%$ isolated yield).

\section{Data for 3q:}

${ }^{1} \mathrm{H}$ NMR: $\left(400 \mathrm{MHz}, \mathrm{CDCl}_{3}\right)$

$7.48(\mathrm{~m}, 1 \mathrm{H}) ; 6.94(\mathrm{~m}, 3 \mathrm{H}) ; 5.41(\mathrm{t}, J=4.0 \mathrm{~Hz}, 1 \mathrm{H}) ; 4.18(\mathrm{dd}, J=5.0,5.2 \mathrm{~Hz}$, $2 \mathrm{H}) ; 2.24(\mathrm{~m}, 2 \mathrm{H}) ; 1.94(\mathrm{~m}, 2 \mathrm{H})$

${ }^{13} \mathrm{C}$ NMR: $\left(100 \mathrm{MHz}, \mathrm{CDCl}_{3}\right)$

$156.8 ; 151.6 ; 130.6 ; 129.2 ; 126.2 ; 120.8 ; 111.6 ; 102.4 ; 66.8 ; 56.0 ; 22.8 ; 21.4$

MS: $\quad$ (low resolution): calculated for $\mathrm{C}_{12} \mathrm{H}_{14} \mathrm{O}_{2} 190$, found $\mathrm{m} / \mathrm{z}=190$.

TLC: $\quad \mathrm{R}_{\mathrm{f}} 0.40\left(\mathrm{SiO}_{2}\right.$, hexane / EtOAc, $\left.30 / 1\right)$

GC: $\quad \mathrm{t}_{\mathrm{R}} \mathbf{3 q}, 10.96 \mathrm{~min}\left(\mathrm{HP} 5890\right.$; injector $250^{\circ} \mathrm{C}$, column gradient $50^{\circ} \mathrm{C}$ for $4 \mathrm{~min}$, $25^{\circ} \mathrm{C}$ per min to $200^{\circ} \mathrm{C}, 200^{\circ} \mathrm{C}$ for $8 \mathrm{~min} ; 8.4 \mathrm{psi}$ ) 


\section{General Procedure for $C$-Aryl Glycal Synthesis}

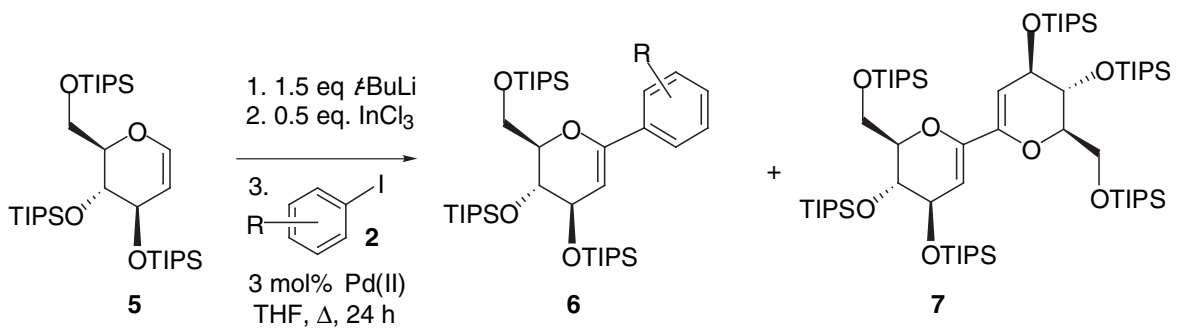

To a stirred solution of $0.5 \mathrm{ml}$ of dry THF and TIPS glucal $5(615 \mathrm{mg}, 1 \mathrm{mmol})$ was added dropwise a solution of tert-butyllithium ( $1 \mathrm{~mL}, 1.67 \mathrm{mmol}, 1.7 \mathrm{M}$ in pentane) at $-78^{\circ} \mathrm{C}$ under dry $\mathrm{N}_{2}$. The resulting yellow solution was allowed to warm to $0^{\circ} \mathrm{C}$ and stirred at that temperature for 1.5 hour. The solution was again cooled to $-78^{\circ} \mathrm{C}$ and was added dropwise via cannula to a solution of indium(III) chloride $(121 \mathrm{mg}, 0.55 \mathrm{mmol})$ in dry THF $(0.5 \mathrm{ml})$ at $-78^{\circ} \mathrm{C}$. The mixture was stirred at this temperature for 30 minutes and was then allowed to warm to room temperature, during which time a yellow suspension formed.

To this solution was added aryl iodide (1.0-1.5 eq) and $\mathrm{Cl}_{2} \mathrm{Pd}\left(\mathrm{PPh}_{3}\right)_{2}(21 \mathrm{mg}, 3$ mol\%) and a condenser was attached to the reaction, and the mixture was stirred at $70^{\circ} \mathrm{C}$ for $12 \mathrm{~h}$. At this time tlc analysis indicated the presence of $C$-aryl glycal. The cooled reaction mixture was diluted with benzene and a few drops of methanol, and filtered through celite. Concentration in vacuo and flash chromatography $\left(\mathrm{SiO}_{2}\right.$, hexanes->100:1 hexanes:ether) afforded pure $C$-aryl glucal. 


\section{Reaction with 2-iodotoluene 20}<smiles>[R]C1=C[C@H]([OH+])[C@H](O[AsH])[C@H](CO[SnH])O1</smiles>

5

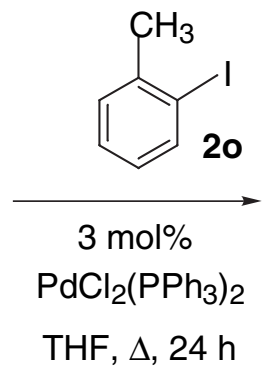

THF, $\Delta, 24 \mathrm{~h}$<smiles>Cc1ccccc1C1=C[C@H]([OH+])[C@H](O[AsH3])[C@H](COC(F)(F)F)O1</smiles>

60

$\mathrm{R}=\ln (\mathrm{III})$

Following the general procedure, 2-iodotoluene $20(0.15 \mathrm{ml}, 1.1 \mathrm{mmol})$ was added to the previously prepared THF solution of $5(\mathrm{R}=\mathrm{In}(\mathrm{III}))$ along with $\mathrm{Cl}_{2} \mathrm{Pd}\left(\mathrm{PPh}_{3}\right)_{2}$ $(21 \mathrm{mg}, 3 \mathrm{~mol} \%)$. A reflux condenser was attached to the reaction, and the mixture was stirred at $70^{\circ} \mathrm{C}$ for $24 \mathrm{~h}$. At this time tlc analysis indicated the presence of $C$-aryl glycal 6o. The cooled reaction mixture was diluted with benzene and a few drops of methanol, and filtered through celite. Concentration in vacuo and flash chromatography $\left(\mathrm{SiO}_{2}\right.$, hexanes) afforded $C$-aryl glucal 60 (420 mg, 0.6mmol, 60\%).

Data for 6o:

1'H NMR: $\left(400 \mathrm{MHz}, \mathrm{CDCl}_{3}\right)$

$7.28-7.14(\mathrm{~m}, 4 \mathrm{H}) ; 4.94(\mathrm{dd}, J=5.6,1.6 \mathrm{~Hz}, 1 \mathrm{H}) ; 4.44(\mathrm{td}, J=4.8,2.8 \mathrm{~Hz}$, $1 \mathrm{H}) ; 4.22-4.16(\mathrm{~m}, 3 \mathrm{H}) ; 4.03(\mathrm{dd}, J=11.2,5.6 \mathrm{~Hz}, 1 \mathrm{H}) ; 2.44(\mathrm{~s}, 1 \mathrm{H}) ; 1.10-$ $0.91(\mathrm{~m}, 63 \mathrm{H})$

${ }^{13} \mathrm{C}$ NMR: $\left(100 \mathrm{MHz}, \mathrm{CDCl}_{3}\right)$

$153.2 ; 137.5 ; 130.5 ; 129.5 ; 128.7 ; 126.2 ; 125.7 ; 99.7 ; 82.1 ; 69.9 ; 66.8 ; 62.6$; $20.3 ; 18.6 ; 18.5 ; 12.8 ; 12.4$

MS: $\quad(\mathrm{FAB}+)$ calculated for $\mathrm{C}_{40} \mathrm{H}_{75} \mathrm{O}_{4} \mathrm{Si}_{3} \mathrm{Na} 703.4973$, found $m / z=703.4996(\mathrm{M}-$ $\mathrm{H})^{+}$

TLC: $\quad \mathrm{R}_{\mathrm{f}} 0.17\left(\mathrm{SiO}_{2}\right.$, petroleum ether)

IR: $\quad 2943,2866,1658.0 \mathrm{~cm}^{-1}$ 


\section{$\underline{\text { Reaction with 4-iodoacetophenone 2a }}$}

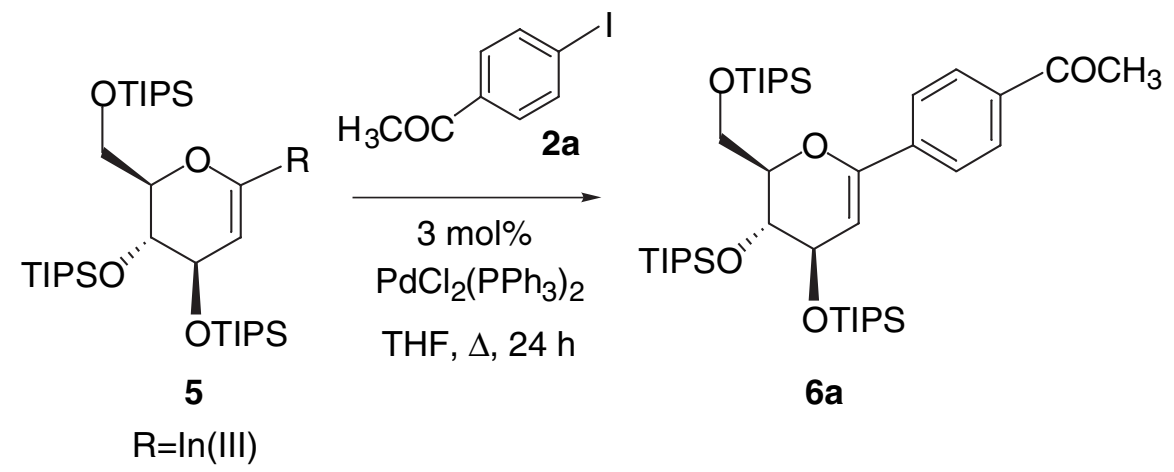

Following the general procedure, 4-iodoacetophenone 2a (245mg, 1 mmol, $1.0 \mathrm{eq})$ was added to the previously prepared THF solution of $5(\mathrm{R}=\mathrm{In}(\mathrm{III}))$ along with $\mathrm{Cl}_{2} \mathrm{Pd}\left(\mathrm{PPh}_{3}\right)_{2}(21 \mathrm{mg}, 3 \mathrm{~mol} \%)$. A reflux condenser was attached to the reaction, and the mixture was stirred at $70^{\circ} \mathrm{C}$ for $24 \mathrm{~h}$. At this time, tlc analysis indicated the presence of $C$-aryl glycal 6a. The cooled reaction mixture was diluted with benzene and a few drops of methanol, and filtered through celite. Concentration in vacuo and flash chromatography $\left(\mathrm{SiO}_{2}\right.$, hexanes->100:1 hexanes:ether) afforded $C$-aryl glucal 6a (400mg, $0.55 \mathrm{mmol}, 55 \%$ yield).

Data for 6a:

H NMR: $\left(400 \mathrm{MHz}, \mathrm{CDCl}_{3}\right)$

$7.91(\mathrm{~d}, J=6.8 \mathrm{~Hz}, 2 \mathrm{H}) ; 7.74(\mathrm{~d}, J=6.8 \mathrm{~Hz}, 2 \mathrm{H}) ; 5.49(\mathrm{~d}, J=6.4 \mathrm{~Hz}, 1 \mathrm{H})$;

$4.50(\mathrm{~m}, 1 \mathrm{H}) ; 4.14-4.20(\mathrm{~m}, 3 \mathrm{H}) ; 3.87(\mathrm{dd} ; J=11.6,6.4 \mathrm{~Hz}, 1 \mathrm{H}) ; 2.62(\mathrm{~s}, 3 \mathrm{H})$;

$1.02-1.10(\mathrm{~m} .63 \mathrm{H})$

${ }^{13} \mathrm{C}$ NMR: $\left(100 \mathrm{MHz}, \mathrm{CDCl}_{3}\right)$

$198.0 ; 149.7 ; 141.0 ; 137.1 ; 128.5 ; 125.7 ; 99.3 ; 81.9 ; 70.4 ; 66.9 ; 62.3 ; 27.0 ;$ $18.6-18.3 ; 12.9 ; 12.8 ; 12.4$

MS: $\quad(\mathrm{FAB}+)$ calculated for $\mathrm{C}_{41} \mathrm{H}_{77} \mathrm{O}_{5} \mathrm{Si}_{3} 733.5079$, found $m / z=733.5102(\mathrm{M}+\mathrm{H})^{+}$

TLC: $\quad \mathrm{R}_{\mathrm{f}} 0.53\left(\mathrm{SiO}_{2}\right.$, hexane / $\mathrm{Et}_{2} \mathrm{O} /$ ethyl acetate, $\left.100 / 1 / 1\right)$

IR: $\quad 2975,2866,1688,1651 \mathrm{~cm}^{-1}$ 
$\underline{\text { Reaction with methyl-2-iodobenzoate 2d }}$<smiles>[R]C1=C[C@H]([OH+])[C@H](O[AsH2])[C@H](CO[SnH])O1</smiles>

5

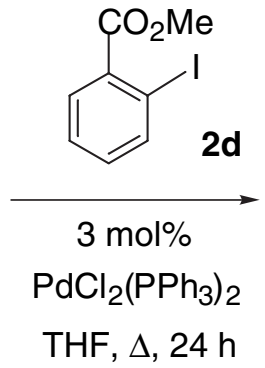

$\mathrm{R}=\ln (\mathrm{III})$<smiles>COC(=O)c1ccccc1C1=C[C@H](O[Na])[C@H](O[AsH])[C@H](COC(F)(F)F)O1</smiles>

$6 d$

Following the general procedure, methyl-2-iodobenzoate $2 \mathbf{d}(0.2 \mathrm{ml}, 1.4 \mathrm{mmol})$ was added to the previously prepared THF solution of $5(\mathrm{R}=\mathrm{In}(\mathrm{III}))$ along with $\mathrm{Cl}_{2} \mathrm{Pd}\left(\mathrm{PPh}_{3}\right)_{2}(21 \mathrm{mg}, 3 \mathrm{~mol} \%)$. A reflux condenser was attached to the reaction, and the mixture was stirred at $70^{\circ} \mathrm{C}$ for $24 \mathrm{~h}$. At this time tlc analysis indicated the presence of $C$ aryl glycal 6d. The cooled reaction mixture was diluted with benzene and a few drops of methanol, and filtered through celite. Concentration in vacuo and flash chromatography $\left(\mathrm{SiO}_{2}\right.$, hexanes->100:1 hexanes:ether) afforded pure $C$-aryl glucal 6d (402 mg, $0.54 \mathrm{mmol}, 54 \%$ yield).

Data for 6d:

${ }^{1} \mathrm{H}$ NMR: $\quad\left(400 \mathrm{MHz}, \mathrm{CDCl}_{3}\right)$

$7.63(\mathrm{~d}, J=7.2 \mathrm{~Hz}, 1 \mathrm{H}) ; 7.34-7.50(\mathrm{~m}, 3 \mathrm{H}) ; 5.03(\mathrm{~d}, J=5.2 \mathrm{~Hz}, 1 \mathrm{H}) ; 4.38(\mathrm{t}$, $J=6.8 \mathrm{~Hz}, 1 \mathrm{H}) ; 4.27(\mathrm{~s}, 1 \mathrm{H}) ; 4.10-4.23(\mathrm{~m}, 3 \mathrm{H}) ; 3.83(\mathrm{~s}, 3 \mathrm{H}) ; 0.97-1.27(\mathrm{~m}$, $63 \mathrm{H})$

${ }^{13} \mathrm{C} \mathrm{NMR:}\left(100 \mathrm{MHz}, \mathrm{CDCl}_{3}\right)$

$207.1 ; 169.4 ; 151.9 ; 131.8 ; 131.0 ; 130.0 ; 129.3 ; 128.6 ; 99.7 ; 81.9 ; 70.0 ; 67.3$; $62.0 ; 52.4 ; 31.2 ; 18.6-18.1 ; 13.3,12.4$

MS: $\quad(\mathrm{FAB}+)$ calculated for $\mathrm{C}_{41} \mathrm{H}_{75} \mathrm{O}_{6} \mathrm{Si}_{3} 747.4872$, found $m / z=747.4903(\mathrm{M}-\mathrm{H})^{+}$

TLC: $\quad \mathrm{R}_{\mathrm{f}} 0.34\left(\mathrm{SiO}_{2}\right.$, hexane / $\left.\mathrm{Et}_{2} \mathrm{O}, 100 / 1\right)$

IR: $\quad 2943,2875,1738,1662 \mathrm{~cm}^{-1}$ 


\section{Reaction with 2-iodonapthalene $\mathbf{2 h}$}<smiles>[R]C1=C[C@H]([OH+])[C@H](O[AsH])[C@H](CO[SnH])O1</smiles>

5

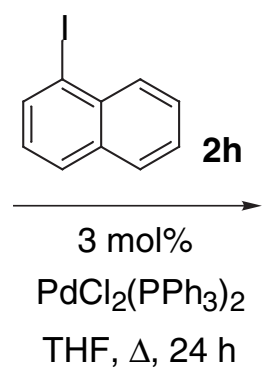

$\mathrm{THF}, \Delta, 24 \mathrm{~h}$<smiles>FC(F)(F)O[C@H]1[C@H](OC(F)(F)F)C=C(c2cccc3ccccc23)O[C@@H]1COP(F)(F)=S</smiles>

$6 h$

$\mathrm{R}=\ln (\mathrm{III})$

Following the general procedure, 1-iodonaphthalene $\mathbf{2 h}(0.2 \mathrm{ml}, 1.4 \mathrm{mmol})$ was added to the previously prepared THF solution of $5(\mathrm{R}=\mathrm{In}(\mathrm{III}))$ along with $\mathrm{Cl}_{2} \mathrm{Pd}\left(\mathrm{PPh}_{3}\right)_{2}$ (21 $\mathrm{mg}, 3 \mathrm{~mol} \%$ ). A reflux condenser was attached to the reaction, and the mixture was stirred at $70^{\circ} \mathrm{C}$ for $24 \mathrm{~h}$. At this time tlc analysis indicated the presence of $C$-aryl glycal 6h. The cooled reaction mixture was diluted with benzene and a few drops of methanol, and filtered through celite. Concentration in vacuo and flash chromatography $\left(\mathrm{SiO}_{2}\right.$, hexanes) afforded $C$-aryl glucal $6 \mathbf{h}(435 \mathrm{mg}, 0.59 \mathrm{mmol}, 59 \%$ yield).

Data for 6h:

${ }^{1} \mathrm{H}$ NMR: $\left(400 \mathrm{MHz}, \mathrm{CDCl}_{3}\right)$

$7.84(\mathrm{dd}, J=8.0,4.0 \mathrm{~Hz}, 2 \mathrm{H}) ; 7.53-7.43(\mathrm{~m}, 5 \mathrm{H}) ; 5.16(\mathrm{dd}, J=3.6,2.4 \mathrm{~Hz}$, $1 \mathrm{H}) ; 4.56(\mathrm{~m}, 1 \mathrm{H}) ; 4.27-4.16(\mathrm{~m}, 4 \mathrm{H}) ; 1.07-1.17(\mathrm{~m}, 63 \mathrm{H})$

${ }^{13} \mathrm{C} \mathrm{NMR:}\left(100 \mathrm{MHz}, \mathrm{CDCl}_{3}\right)$

$152.7 ; 143.4 ; 135.9 ; 134.0 ; 132.1 ; 129.2 ; 128.3 ; 127.0 ; 126.8 ; 126.3 ; 126.1$; $125.4 ; 101.1 ; 82.3 ; 70.0 ; 66.9 ; 18.4 ; 12.8$

MS: $\quad(\mathrm{FAB}+)$ calculated for $\mathrm{C}_{43} \mathrm{H}_{75} \mathrm{O}_{4} \mathrm{Si}_{3} 739.4973$, found $m / z=739.5015(\mathrm{M}-\mathrm{H})^{+}$

TLC: $\quad \mathrm{R}_{\mathrm{f}} 0.32\left(\mathrm{SiO}_{2}\right.$, hexanes / benzene / ether, $\left.196 / 4 / 1\right)$

IR: $\quad 2959,2840,1646.4 \mathrm{~cm}^{-1}$ 


\section{Reaction with 2-iodoanisole 2q}

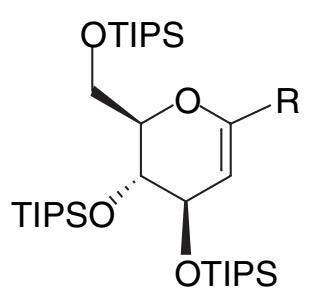

5

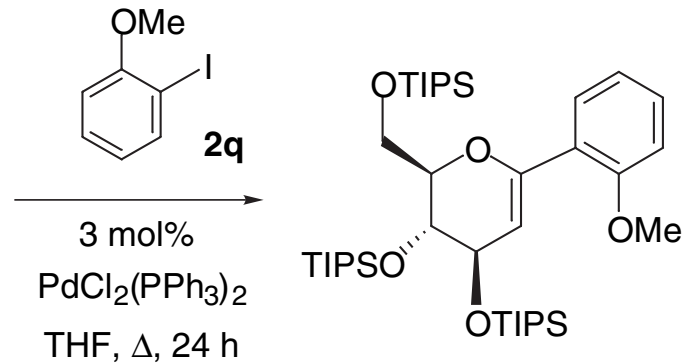

$6 q$

$\mathrm{R}=\ln (\mathrm{III})$

Following the general procedure, 2-iodoanisole $\mathbf{2 q}(0.18 \mathrm{ml}, 1.35 \mathrm{mmol})$ was added to the previously prepared THF solution of $5(\mathrm{R}=\mathrm{In}(\mathrm{III}))$ along with $\mathrm{Cl}_{2} \mathrm{Pd}\left(\mathrm{PPh}_{3}\right)_{2}$ $(21 \mathrm{mg}, 3 \mathrm{~mol} \%)$. A reflux condenser was attached to the reaction, and the mixture was stirred at $70^{\circ} \mathrm{C}$ for $24 \mathrm{~h}$. At this time tlc analysis indicated the presence of $C$-aryl glycal. The cooled reaction mixture was diluted with benzene and a few drops of methanol, and filtered through celite. Concentration in vacuo and flash chromatography $\left(\mathrm{SiO}_{2}, 200: 1\right.$ hexanes:ether) afforded $C$-aryl glucal $6 q$ (430 $\mathrm{mg}, 0.6 \mathrm{mmol}, 60 \%$ yield).

Data for 6q:

${ }^{1} \mathrm{H}$ NMR: $\left(400 \mathrm{MHz}, \mathrm{CDCl}_{3}\right)$

$7.56(\mathrm{dd}, J=7.6,2.4 \mathrm{~Hz}, 1 \mathrm{H}) ; 7.26(\mathrm{td}, J=6.4,1.6 \mathrm{~Hz}, 1 \mathrm{H}) ; 6.95(\mathrm{t}, J=7.6 \mathrm{~Hz}$, $1 \mathrm{H}) ; 6.88(\mathrm{~d}, J=8 \mathrm{~Hz}, 1 \mathrm{H}) ; 5.49(\mathrm{~m}, 1 \mathrm{H}) ; 4.42(\mathrm{~m}, 1 \mathrm{H}) ; 4.18-4.10(\mathrm{~m}, 3 \mathrm{H})$; $4.05(\mathrm{dd}, J=11.3,6.4 \mathrm{~Hz}, 1 \mathrm{H}) ; 3.81(\mathrm{~s}, 3 \mathrm{H}) ; 1.03-1.11(\mathrm{~m}, 63 \mathrm{H})$

${ }^{13} \mathrm{C}$ NMR: $\left(100 \mathrm{MHz}, \mathrm{CDCl}_{3}\right)$

$157.6 ; 148.1 ; 129.8 ; 129.3 ; 120.6 ; 111.8 ; 101.6 ; 81.5 ; 70.4 ; 67.3 ; 62.4 ; 55.9$; $18.6-18.4 ; 12.9,12.7$

MS: $\quad(\mathrm{FAB}+)$ calculated for $\mathrm{C}_{40} \mathrm{H}_{75} \mathrm{O}_{5} \mathrm{Si}_{3} 719.4922$, found $m / z=719.4909(\mathrm{M}-\mathrm{H})^{+}$

TLC: $\quad \mathrm{R}_{\mathrm{f}} 0.66\left(\mathrm{SiO}_{2}\right.$, hexane / ether, $\left.100 / 1\right)$

IR: $\quad 2941,2865,1643 \mathrm{~cm}^{-1}$ 


\section{Reaction with 4-iodoanisole 2p}

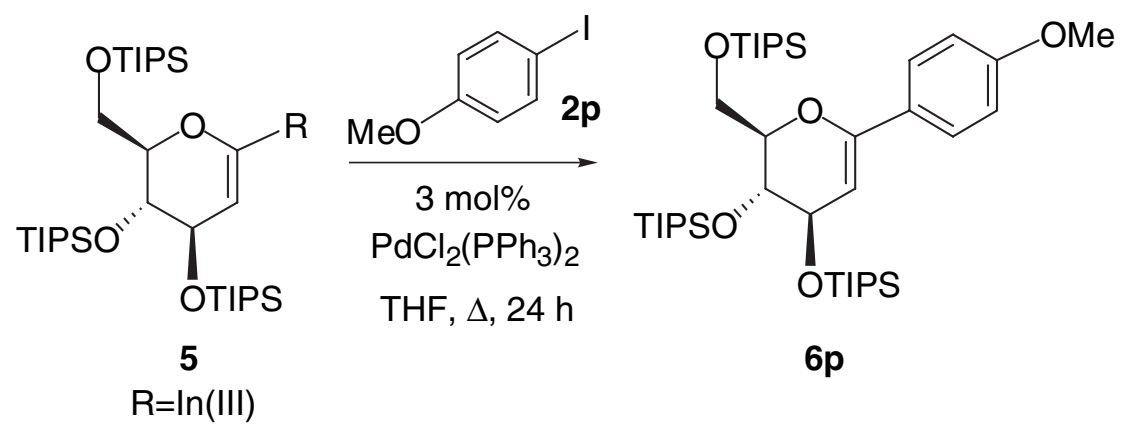

Following the general procedure, 4-iodoanisole $2 \mathbf{p}(0.18 \mathrm{ml}, 1.35 \mathrm{mmol})$ was added to the previously prepared THF solution of $5(\mathrm{R}=\mathrm{In}(\mathrm{III}))$ along with $\mathrm{Cl}_{2} \mathrm{Pd}\left(\mathrm{PPh}_{3}\right)_{2}$ (21 $\mathrm{mg}, 3 \mathrm{~mol} \%$ ). A reflux condenser was attached to the reaction, and the mixture was stirred at $70^{\circ} \mathrm{C}$ for $24 \mathrm{~h}$. At this time tlc analysis indicated the presence of $C$-aryl glycal. The cooled reaction mixture was diluted with benzene and a few drops of methanol, and filtered through celite. Concentration in vacuo and flash chromatography $\left(\mathrm{SiO}_{2}, 100: 1\right.$ hexanes:ether) afforded pure $C$-aryl glucal $6 \mathbf{p}$ ( $285 \mathrm{mg}, 0.4 \mathrm{mmol}, 40 \%$ yield).

Data for 6p:

${ }^{1} \mathrm{H}$ NMR: $\left(400 \mathrm{MHz}, \mathrm{CDCl}_{3}\right)$

$7.58(\mathrm{dd}, J=6.8,2.4 \mathrm{~Hz}, 2 \mathrm{H}) ; 6.87(\mathrm{dd}, J=6.8,2.4 \mathrm{~Hz}, 2 \mathrm{H}) ; 5.25(\mathrm{dd}, J=$

$5.2,1.6 \mathrm{~Hz}, 1 \mathrm{H}) ; 4.45(\mathrm{~m}, 1 \mathrm{H}) ; 4.20-4.06(\mathrm{~m}, 3 \mathrm{H}) ; 3.91(\mathrm{dd}, J=11.0,6.2$ $\mathrm{Hz}, 1 \mathrm{H}) ; 3.81(\mathrm{~s}, 3 \mathrm{H}) ; 1.09-1.01(\mathrm{~m}, 63 \mathrm{H})$.

${ }^{13} \mathrm{C} \mathrm{NMR}:\left(100 \mathrm{MHz}, \mathrm{CDCl}_{3}\right)$

$160.0 ; 150.4 ; 127.1 ; 113.7 ; 95.6 ; 81.7 ; 70.6 ; 67.3 ; 62.5 ; 55.6 ; 18.3 ; 12.9$

MS: $\quad(\mathrm{FAB}+)$ calculated for $\mathrm{C}_{40} \mathrm{H}_{75} \mathrm{O}_{5} \mathrm{Si}_{3} 719.4922$, found $\mathrm{m} / z=719.4903(\mathrm{M}-\mathrm{H})^{+}$

TLC: $\quad \mathrm{R}_{\mathrm{f}} 0.37\left(\mathrm{SiO}_{2}\right.$, hexane / ether, $\left.300 / 1\right)$

IR: $\quad 2943,2866,1650 \mathrm{~cm}^{-1}$ 


\section{Platinum oxide reduction of $\mathbf{6 0}$}

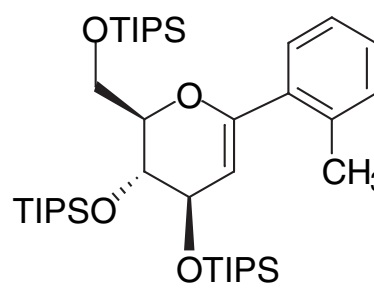

60

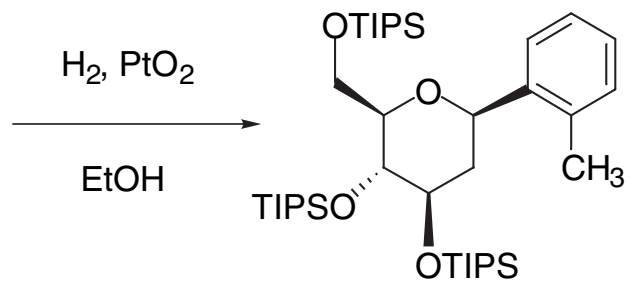

8

$C$-aryl glucal $60(109 \mathrm{mg}, 0.14 \mathrm{mmol})$ was dissolved in $\mathrm{EtOH}(3 \mathrm{~mL})$ and $\mathrm{PtO}_{2}$ (20mg) was added. The system was evacuated and purged with hydrogen gas. After stirring for 30 minutes under an atmosphere of hydrogen, the mixture was filtered through celite and concentrated in vacuo, affording $98 \mathrm{mg}$ (90\% yield) of 2-deoxy- $\beta$ - $C$ aryl glycoside 8; the crude material was sufficiently pure for analysis.

Data for 8:

${ }^{1} \mathrm{H}$ NMR: $\left(400 \mathrm{MHz}, \mathrm{CDCl}_{3}\right)$

$7.50(\mathrm{dd}, J=6.8,1.6 \mathrm{~Hz}, 1 \mathrm{H}) ; 7.21-7.13(\mathrm{~m}, 3 \mathrm{H}) ; 4.74(\mathrm{dd} ; J=10.8,2.0 \mathrm{~Hz}$, $1 \mathrm{H})$; 4.14-3.82 (m, 3H); 3.61-3.58 (m, 1H); 2.35 (s, 3H); 1.17-1.07 (m, 63H).

${ }^{13} \mathrm{C}$ NMR: $\left(100 \mathrm{MHz}, \mathrm{CDCl}_{3}\right)$

$140.8 ; 135.2 ; 130.4 ; 127.5 ; 126.3 ; 126.0 ; 83.2 ; 75.4 ; 73.2 ; 72.8 ; 69.8 ; 64.6$; $62.3 ; 57.4 ; 40.5 ; 18.6 ; 14.1 ; 12.8$

MS: $\quad(\mathrm{FAB}+)$ calculated for $\mathrm{C}_{40} \mathrm{H}_{78} \mathrm{O}_{4} \mathrm{Si}_{3} \mathrm{Na} 729.5106$, found $\mathrm{m} / z=729.5112(\mathrm{M}+$ $\mathrm{Na})^{+}$

TLC: $\quad \mathrm{R}_{\mathrm{f}} 0.45\left(\mathrm{SiO}_{2}\right.$, hexanes $)$

IR: $\quad 2950,2865 \mathrm{~cm}^{-1}$ 


\section{Hydroboration/oxidation of $\mathbf{6 p}$}

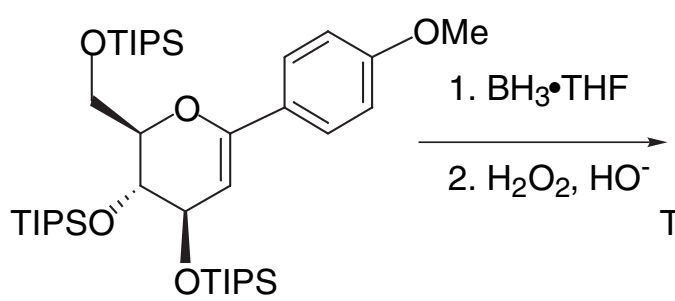

$6 p$<smiles>COc1ccc([C@H]2OC(COC(F)(F)F)[C@H](OC(C)C)[C@H](OC(F)(F)F)[C@H]2O)cc1</smiles>

9

$C$-aryl glucal 6p $(25 \mathrm{mg}, 0.035 \mathrm{mmol})$ was dissolved in THF $(0.1 \mathrm{~mL})$ and $\mathrm{BH}_{3} \bullet \mathrm{THF}(1.5 \mathrm{M}, 0.35 \mathrm{~mL}, 0.53 \mathrm{mmol})$ was added dropwise at $0^{\circ} \mathrm{C}$. The reaction was stirred at ambient temperature for 24 hours and then $3 \mathrm{~N} \mathrm{NaOH} / 30 \% \mathrm{H}_{2} \mathrm{O}_{2}(1: 1,10 \mathrm{ml})$ was added and the reaction was stirred at room temperature for an additional $24 \mathrm{~h}$. The mixture was diluted with $\mathrm{CH}_{2} \mathrm{Cl}_{2}(25 \mathrm{~mL})$, the organic layer was partitioned and washed successively with $20 \% \mathrm{NaHSO}_{3}(25 \mathrm{~mL})$, saturated ammonium chloride $(25 \mathrm{~mL})$, water $(25 \mathrm{~mL})$, and brine $(25 \mathrm{~mL})$. The organic layer was dried over sodium sulfate and concentrated in vacuo. Flash chromatography $\left(\mathrm{SiO}_{2}, 10: 1\right.$ Hexanes:Ether) afforded pure $C$-aryl glycoside 9 (10 mg, 39\%).

Data for 9:

H NMR: $\left(400 \mathrm{MHz}, \mathrm{CDCl}_{3}\right)$

$7.27(\mathrm{~d}, J=8.8 \mathrm{~Hz}, 2 \mathrm{H}) ; 6.87(\mathrm{~d}, J=8.8 \mathrm{~Hz}, 2 \mathrm{H}) ; 4.95(\mathrm{~d}, J=9.5 \mathrm{~Hz}, 1 \mathrm{H})$;

$4.39(\mathrm{td}, J=7.2,3.6 \mathrm{~Hz}, 1 \mathrm{H}) ; 4.15(\mathrm{t}, J=4.4 \mathrm{~Hz}, 1 \mathrm{H}) ; 4.04(\mathrm{~m}, 1 \mathrm{H}) ; 3.87(\mathrm{~d}, J$

$=6.0 \mathrm{~Hz}, 1 \mathrm{H}) ; 3.26(\mathrm{~m}, 1 \mathrm{H}) ; 1.15-1.07(\mathrm{~m}, 63 \mathrm{H})$

${ }^{13} \mathrm{C}$ NMR: $\left(100 \mathrm{MHz}, \mathrm{CDCl}_{3}\right)$

$159.0 ; 137.1 ; 127.3 ; 114.2 ; 74.2 ; 73.4 ; 66.5 ; 55.7 ; 42.8 ; 18.6-18.3 ; 13.2 ; 12.4$.

TLC: $\quad \mathrm{R}_{\mathrm{f}} 0.59\left(\mathrm{SiO}_{2}\right.$, hexane / EtOAc, $\left.10 / 1\right)$

IR: $\quad 3470,2925,2865 \mathrm{~cm}^{-1}$ 